\title{
The Promotion Role of Power System Reform in Operation Mode Change of Power Grid Enterprises
}

\author{
Changzhan Han, Yang Zhao, Guang Tian
}

\author{
State Grid Hebei Electric Power Company, Shijiazhuang HebeiChina, 050021
}

Keywords: Promotion Role, Power system reform, Operation mode, Power grid enterprises.

\begin{abstract}
In the new century, China has been vigorously developing electric power enterprises, and power system is constantly reforming. With in-depth power system reform, power grid enterprises began to have further thought on existing business models and make some corresponding changes. Power sales reform is the biggest bright spot in the new round of power system reform, marking the complete destruction of an exclusive monopoly distribution system in China's power grid company. For the current round of power system reform, how power grid enterprises should react is the focus in current issues. In this paper, the promotion role of power system reform in operation mode change of power grid enterprises is discussed briefly.
\end{abstract}

With the official release of "Number of Opinions on Further Deepening of Power System Reform" (hereinafter referred to as new power reform) on March 15, 2015, after 12 years, China's new round of power system reform begins. From new power reform policy analysis direction, grid enterprises' existing operation modes will have a huge change and their core position will change. With the gradual improvement of electricity reform, lower electricity price is not the focus of the reform. Grid companies' biggest problem is that in a long overdue, they maintain serious thinking rigid without enough flexibility. The approval process is too long and some aspects ability extremely lags behind.

Future power generation plan and electricity price will be released, and the incremental part of power distribution and power sale will be released to allow social and private capital to enter. Power companies and power generation enterprises can directly negotiate electricity prices, which will break the monopoly business model in original unified purchase and sale and build a fully competitive market power trading platform as the final result.

\section{The Original and Future Operation Mode of Power Grid Enterprises}

In 1997, China's power supply and demand situation was changed and there was a situation of oversupply in most of the country, then many deep problems in power systems became increasingly prominent. In this context, China accelerated the pace of construction of electricity market. Based on 2002 power system reform, a new round of power system reform was launched in 2014 [1]. The last round of electricity made the main solution to the separation of plant and network, and the new power reform focused on power transmission and distribution, and now six supporting documents have been issued, such as power distribution reform, power market construction, power trading institutions set-up and regulated operation, well-aligned development of power consumption plan, power sale reform, strengthening and regulation of coal-fired power plant supervision and management.

A. Original operation mode of power grid enterprises

Grid enterprises have natural monopoly and power grid enterprises have little market competition awareness. They have no better quality of service and good power marketing program, and did not form an effective market management marketing system. Power marketing refers to a series of marketing activities related to market sales to meet the needs of consumers and better profitability. The fundamental purpose is to provide consumers with better products and services 
and win more consumption to create the most comprehensive business benefits.

B. Future operation mode of power grid enterprises

With the gradual promotion of new power reform, future power industry and power grid enterprises monopoly will be more scientific and reasonable, which will also be reflected in the improvement of unified grid dispatch and management level [2]. China's power grid enterprises have always been duopoly characteristics. The current round of power reform makes supervision on the permitted total revenue (permitted cost + reasonable income + tax) and price structure through the approved effective assets for grid enterprises. The same period of reform involves supply side reform, state-owned enterprises reform superposition and a number of reform jobs implicate each other. Power grid enterprises should rely on their own cost control advantages and power plant cluster management advantages, and the market-oriented measures pilot work of large users' direct purchase of electricity has been gradually implemented in the past few years. We should grab the opportunity to deepen the pilot work of buying electricity and the most important work in economically developed key areas is to actively participate in large-scale direct purchase of electricity pilot work. To further enhance the profitability of power grid enterprises and improve power generation time and the total power generation, gradual expansion of electricity direct purchase proportion is undoubtedly a high-quality program.

\section{The Promotion Role of Power System Reform in Power Grid Enterprises}

A. Power grid enterprise structure promotion

China's new power reform gradually goes deeper and reform programs have fierce competition and still difficult to get the best. Various stakeholders' specific measures of the reform vary and there is a big controversy especially whether there is the need for a certain separation in transmission and distribution. Electric power system reform may have no impact on power supply administration, but it impacts power grid enterprises. An important reason is that if power transmission and distribution enterprises should be separated from electricity sales enterprises. China's power reform can cross "whether the separation of power transmission and distribution network" by learning from other countries, making transaction rules of market access and competition effective market rules, and introducing main market players and strengthened supervision and other aspects. The separation of transmission and distribution does not mean that the inevitable success of the reform and under the conditions of transmission and distribution together, there is also a precedent for reform success. Although they are different and respective reform models, some developed countries' optimization of power system is achieved through market-oriented new power reform.

The core content of new power reform program is to establish a new profit model of power grid enterprises, which no longer takes Internet and sales electricity price difference as a source of income, but charges network fees in accordance with government approved transmission and distribution price. Although some issues have reached a consensus, there is still a need to finalize some of the details. Power grid enterprises are now in urgent need of research to face key issues like how to promote the transformation of power grid business mode, fill short board, and save unnecessary waste of resources.

B. The promotion role in power grid business model

In terms of power grid companies, company's operating performance data vary and even have greater differences. It can be seen that the factors influencing the development of power grid enterprises in their own business are: resource allocation, external objective environment, self-condition and other comprehensive factors because the main income of China's power grid enterprises is from electricity trading difference [3]. At the same time, the social optimal solution of power generation market management competition problem is determined. This will also greatly reduce the benefits. Competitive analysis of power generation market is made and the need of government regulation is put forward [4]. Power grid enterprises should rely on their own cost control advantages and power plant cluster management advantages, and large users direct purchase market-oriented measures pilot work has been gradually implemented in the past few years. 


\section{The promotion role in grid business management}

The original power grid enterprises have little market competition awareness and they have no better quality of service and good power marketing program, nor effective market management marketing system. Distribution network planning was originally planned by the planning department of grid enterprise unified planning, and the region's power distribution network construction is also carried out after the adoption of government audit [5]. Therefore, Government stresses transmission and distribution price transparency which will help to form a reasonable transmission and distribution price. Electricity marketing refers to a series of marketing activities related to market sales to meet the needs of consumers, better profitability and then market, and its fundamental purpose is to provide consumers with better products and services, to win more consumption and to create the most comprehensive business benefits. On the one hand, according to the characteristics of the enterprises as well as different planning and development, make effective and planned investment and construction in new distribution network project. On the other hand, select the latter in "waiting for customers to the door" and "take the initiative", and actively go out to seek cooperation customers. Open up the market, increase supply promotions, and change the traditional way.

D. The promotion direction in power enterprise management

Electric power companies should seize the opportunity that the nation is vigorously promoting the development of clean energy nodes, and vigorously develop wind power, light, and water, marine and other clean energy. Seize the existing energy approach business, improve the corresponding industrial chain, and improve corporate brand strength and industrial chain through the active development of clean energy. Grid companies need to determine the focus of different clean energy development based on different geography and different characteristics. For example, focus on the development of distributed power generation based on clean energy according to its power intensiveness and high electricity load characteristic in the eastern region. This is decided by the characteristics of its clean energy and rich resources. Energy is the material basis of human activity. In a sense, the development of human society is inseparable from the emergence of high quality energy and the use of advanced energy technologies. In today's world, the development of energy, energy and environment is a common concern of the entire world and all mankind. It is also an important issue in China's social and economic development. We should promote the diversified clean energy development and cultivate strategic emerging industries. Grid scheduling priority table is as follows.

Table 1 Grid Scheduling Priority

\begin{tabular}{|c|c|c|c|c|}
\hline Level 1 & Level 2 & Level 3 & \multicolumn{2}{|c|}{ Level 4} \\
\hline $\begin{array}{l}\text { Wind, light, water, marine, } \\
\text { biomass, geothermal, } \\
\text { garbage and other renewable } \\
\text { energy power generation }\end{array}$ & $\begin{array}{l}\text { Nuclear power } \\
\text { generation }\end{array}$ & $\begin{array}{l}\text { Cogeneration and gas } \\
\text { power generation }\end{array}$ & $\begin{array}{l}\text { Coal-fired } \\
\text { generation }\end{array}$ & power \\
\hline
\end{tabular}

\section{The Main Problems and Corresponding Solutions Grid Companies Face}

China's electricity price reform has always been lagging behind and has not been able to form a price system which can guide power investment and make users reasonably use electricity. There is no price rule that accords with current policy. After new power reform, we should grasp the micro-grid or the rapid development of market opportunities.

A. Trading institutions and power market construction assort

Electric power market construction model is "nation- region- province", while grid enterprise is to adhere to "state - province" mode of construction. Both of the existing operations are different, and one of the tasks that grid companies need to complete in the early stages is to determine the appropriate regional spot market model and construction phase.

B. Power plan release

One of the important components of power market system construction is power generation plan 
release, and the following four are the work we must do to orderly promote power grid enterprises and government cooperation.

First, handle the relationship between good utility electricity and electricity generation. Under normal circumstances, the planned part of electricity generation should be shared by market members, such as when renewable energy power generation province's public power consumption is lower than the amount of regulated power generation, the two unmatched amount requires the reducing of market power to adjust the difference.

Second, make the co-ordination of a good plan and market. The proportion of electricity generated to participate in market requires reasonable control. We need to balance the interest relationship between market power generation business and users in and out of participation of the market. In the early stages of reform, it should be ensured that the basic operating costs of most power generation enterprises are maintained by the proceeds of the planned electricity supply.

Third, control the conditions of self-owned power plants. This ensures local power supply and investment to promote local economic development. The self-provided power plant, which is affected by the characteristics of power generation, does not enter market transaction in principle and performs auxiliary service obligation, and the balance can participate in market transaction. It is recommended to determine the balance of self-power plant incorporated in the regulated power generation plan according to the principle of cost compensation. But the proportion of self-owned power plants is rising with more small coal-fired units which are not conducive to achieve energy-saving targets because of high energy consumption and heavy pollution.

Fourth, control power market quasi-conditions. The purchase cost and benefit of grid companies will be directly affected by power structure involved in market transaction. The reform of transmission and distribution price will help to promote the process of competitive electricity market and provide the basis for the construction of the pricing mechanism of electricity price. At the same time, new program emphasizes the release of power distribution and incremental part of electricity sales, allowing private capital to enter. This will introduce more market competitors in electricity sales, which is conducive to the formation of market pricing mechanism.

\section{Conclusion}

Although China's new power reform strikes traditional power industry, China's power grid enterprises are ushered in a new spring. We should grasp the micro-grid and the market opportunities of rapid development after the new round of power reform. It has made contributions also in the large-scale implementation of China's new power system. Power system is in the continuous reform and power system reform is in depth, which makes grid business enterprises to consider the existing business model and make corresponding changes. The change has played a catalytic role in the transformation of the operation mode of grid enterprises.

\section{References}

[1] Shen Hongyu, Chen Jin, Gui Sanrong.Effects and countermeasures of the new round of power reform on the distribution network planning of power grid enterprises [J]. Electric Power Construction, 2016, 37 (3): 47-51.

[2] Chen Hongbing.Power grid enterprises development analysis under the background of new round power system reform [J]. China market, 2017 (10): 176-177.

[3] Ma Li, Huang Liming, Xue Song. Key issues in China's new round of power market reform pilot orderly operation [J]. China Electric Power, 2017, 50 (4): 17-22.

[4] Chen Zhen, Cui Feng, Xia Xudong.Effects of power reform on existing power grid and its marketing model [J]. Journal of National University of Technology, 2016, 19 (2): 24-28.

[5] Liu Yue, Liu Feng'e. Challenges and countermeasures of power grid enterprise development under new electricity reform situation [J]. Guangxi Electric Power Industry, 2015, 18 (6): 69-71. 